Meta

Journal des traducteurs

Translators' Journal

\title{
Womanhandling Ibsen's A Doll's House: Feminist Translation Strategies in a Spanish Translation from 1917
}

\section{Iris Muñiz}

Volume 63, numéro 2, août 2018

URI : https://id.erudit.org/iderudit/1055146ar

DOI : https://doi.org/10.7202/1055146ar

Aller au sommaire du numéro

Éditeur(s)

Les Presses de l’Université de Montréal

ISSN

0026-0452 (imprimé)

1492-1421 (numérique)

Découvrir la revue

Citer cet article

Muñiz, I. (2018). Womanhandling Ibsen's A Doll's House: Feminist Translation Strategies in a Spanish Translation from 1917. Meta, 63(2), 422-443.

https://doi.org/10.7202/1055146ar
Résumé de l'article

Cet article analyse une traduction indirecte de 1917 d'Une maison de poupée d’Ibsen (1879) par María Lejárraga (1874-1974), comme un exemple précoce de traduction féministe. Sur la base des conclusions théoriques qui découlent de l'intersection entre les études de genre et la traduction, j'y propose une méthode pour analyser diverses stratégies de traduction comme un moyen de féminiser le texte littéraire en renforçant l'interprétation féministe dont le texte a fait l'objet à l'international, renforcer le débat féministe émergent dans l'Espagne de l'Âge d'Argent et promouvoir une interprétation spécifique de la pièce. L'importance de cette étude de cas comme exemple de traduction féministe précoce repose sur plusieurs facteurs : (a) ce texte théâtral avait une valeur symbolique dans le féminisme de première vague ; (b) cette traduction en espagnol était répandue en raison de la renommée internationale d'Ibsen et de la renommée nationale du médiateur (ouvert) Gregorio Martinez Sierra ; (c) l'activisme féministe de la traductrice (couverte) a pu motiver le choix de ce texte pour propager une « thèse » qu'elle croyait nécessaire en Espagne à cette époque pour le développement du féminisme ; (d) les nombreuses interventions (textuelles, contextuelles et paratextuelles) retraçables dans la traduction.
Ce document est protégé par la loi sur le droit d'auteur. L'utilisation des services d'Érudit (y compris la reproduction) est assujettie à sa politique d'utilisation que vous pouvez consulter en ligne.

https://apropos.erudit.org/fr/usagers/politique-dutilisation/ 


\title{
Womanhandling Ibsen's A Doll's House: Feminist Translation Strategies in a Spanish Translation from 1917
}

\author{
IRIS MUÑ IZ \\ Universitetet i Oslo, Oslo, Norway \\ iris.muniz@ilos.uio.no
}

\section{RÉSUMÉ}

Cet article analyse une traduction indirecte de 1917 d'Une maison de poupée d'Ibsen (1879) par María Lejárraga (1874-1974), comme un exemple précoce de traduction féministe. Sur la base des conclusions théoriques qui découlent de l'intersection entre les études de genre et la traduction, j'y propose une méthode pour analyser diverses stratégies de traduction comme un moyen de féminiser le texte littéraire en renforçant l'interprétation féministe dont le texte a fait l'objet à l'international, renforcer le débat féministe émergent dans l'Espagne de l'Âge d'Argent et promouvoir une interprétation spécifique de la pièce. L'importance de cette étude de cas comme exemple de traduction féministe précoce repose sur plusieurs facteurs: (a) ce texte théâtral avait une valeur symbolique dans le féminisme de première vague; (b) cette traduction en espagnol était répandue en raison de la renommée internationale d'Ibsen et de la renommée nationale du médiateur (ouvert) Gregorio Martinez Sierra; (c) l'activisme féministe de la traductrice (couverte) a pu motiver le choix de ce texte pour propager une «thèse » qu'elle croyait nécessaire en Espagne à cette époque pour le développement du féminisme; (d) les nombreuses interventions (textuelles, contextuelles et paratextuelles) retraçables dans la traduction.

\begin{abstract}
This article analyzes a 1917 indirect translation of Ibsen's A Doll's House (1879) by María Lejárraga (1874-1974) as an example of early feminist translation. Relying on the existing theoretical outcomes at the intersection of gender and translation studies, it proposes a way of analyzing diverse translation strategies as a means for womanhandling the literary text, and thus making the most of the prevailing feminist interpretation of its international reception while reinforcing the budding feminist debate in Silver Age Spain and facilitating a specific understanding of the play. The importance of this case study as an example of early feminist translation is based on several factors: (a) this theatre text had a symbolic value in first wave feminism; (b) this Spanish translation was widespread due to Ibsen's international fame and the national fame of the (overt) mediator Gregorio Martinez Sierra; (c) the feminist activism of the (covert) translator that made her select the text to spread a "thesis" she deemed necessary in Spain at that time for the developing of feminism; and (d) the numerous interventions at different levels (textual, contextual and paratextual) traceable in the translation.
\end{abstract}

\section{RESUMEN}

Este artículo analiza una traducción indirecta de 1917 de Casa de Muñecas (1879) de Ibsen realizada por María Lejárraga (1874-1974) como un ejemplo temprano de traducción feminista. Apoyándose en las conclusiones teóricas surgidas de la intersección entre los estudios de género y de la traducción, propone analizar diversas estrategias traductoras como una forma de feminizar el texto literario sacando el máximo partido de la interpretación feminista que éste había experimentado en su recepción internacional, a la vez que fomentando el emergente debate feminista en la España de la Edad de Plata y 
potenciando una interpretación concreta de la obra. La importancia de este caso de estudio como ejemplo temprano de traducción feminista se basa en varios factores: (a) el valor simbólico de este texto teatral en el feminismo de primera ola; (b) la amplia difusión de esta traducción debido a la fama internacional de Ibsen y nacional del mediador (público) Gregorio Martínez Sierra; (c) el activismo feminista de la traductora (encubierta) que pudo motivarla a elegir este texto como una forma de difundir una "tesis" que creía necesaria para el desarrollo del feminismo en España; (d) las numerosas intervenciones a distintos niveles (textuales, contextuales y paratextuales) que se pueden encontrar en la traducción.

\section{MOTS-CLÉS/KEYWORDS/PALABRAS CLAVE}

traduction féministe, stratégies de traduction, traduction théâtrale, traductrices dans l'histoire

feminist translation, translation strategies, theatre translation, female translators in history

traducción feminista, estrategias de traducción, traducción teatral, traductoras en la historia

\section{Introduction}

On April 27 $7^{\text {th }}$, 1917, Casa de Muñecas, ${ }^{1}$ a new production of Et Dukkehjem ${ }^{2}$ (better known by its most common English title $A$ Doll's House ${ }^{3}$ ) was lunched by the dramatic company of Gregorio Martínez Sierra, who was an important playwright within the commercial theatre circuit, and at that time director of the Eslava theatre of Madrid. By 1917 A Doll's House had already been translated into Spanish several times - the first translation having been published in $1892 .{ }^{4}$ There were several versions available in print. Although this was not the first time that $A$ Doll's House had been staged in Madrid (Mobarak 2013: 52-62; Gregersen 1936) or indeed in Barcelona, where the play premiered as early as 1893 (Siguán 2003), this new staging and translation can be considered the "great breakthrough" of the play and even of Ibsen in Spain (Ozimek-Maier 1980: 120) in terms of both audience and criticism.

The reason for the new success, to a great extent, can be linked to the mediator(s) behind this new production, the peculiar team that published under the name "Gregorio Martinez Sierra," that must be considered a pseudonym (Blanco 2003: 13) hiding the collaboration of Gregorio Martínez Sierra (1881-1947) and his wife María Lejárraga (1874-1974). Gregorio Martínez Sierra was one of the great renovators of Spanish theatre in the Silver Age: he was simultaneously a director, scenographer, and theatre manager. This put him in a privileged position to tackle the issue of (re-)introducing the highly polemical A Doll's House on the Spanish stage. In parallel, Martínez Sierra had acquired a reputation as a spokesperson for the feminist movement in Spain, being the (overt) author of several short magazine articles on the female question and the development of feminism in Spain and abroad that had been published weekly in the literary magazine Blanco y Negro [White and Black], and later in book form as Cartas a las mujeres de España [Letters to the women of Spain] (1915) and Feminismo, feminidad, españolismo [Feminism, femininity, Spanishness] (1917). Those early feminist essays, as well as the majority of all the writing published under his name (particularly the translations) (Aguilera Sastre 2014, 2016) were originally written by his wife María Lejárraga, as researchers have 
demonstrated since (O’Connor 1987; Blanco 2003). ${ }^{5}$ Lejárraga was a feminist activist who had collaborated with several Spanish and international associations, including the International Woman Suffrage Alliance (IWSA) (Lizárraga Vizcarra and Aguilera Sastre 2010). While it may be difficult to understand her use of her husband's name instead of her own given her feminist ideals, using a male name allowed her to enter the world of theatre, the most difficult domain for women writers (O'Connor 1988: 9). In the Spain of the Silver Age very few women could stage their plays and even fewer could do so more than once or in commercial circuits (Nieva de la Paz 1993: 298-299).

Martinez Sierras's new version of A Doll's House remained on the stage, intermittently, from 1917 to 1936, with almost 200 stagings in several cities in Spain and also in selected areas of America during the tour of 1927-1929 (Buenos Aires, Mexico City, Habana, Caracas). It was the only Spanish version staged during a key period in the development of Spanish feminism. Indeed, Silver Age Spain, that is, the first decades of the twentieth century before the outbreak of the Civil War, was the period where the Spanish equivalent to first wave feminism developped. Given that the hidden author of the translation was a feminist activist herself, who was collaborating with other feminists of her time in different social and cultural enterprises, it is interesting to try to determine to what extent this translation is permeated by that feminist content and how that can be demonstrated at the textual level, as this article shall examine. This is expressly important in the case of Ibsen's text because it has often been utilized as a feminist text in different target cultures (Holledge, Helland, et al. 2016; Templeton 1990; Finney 1994; Farfan 1996; Chang 2004; Langås 2005; Moi 2006; Fischer-Lichte 2011). There is little research about how it specifically influenced the development of first wave feminism in the South of Europe and particularly Spain, and none focusing on the translated texts. This article aims to address that knowledge gap while proposing a way of applying the concept of feminist translation to historical translations.

\section{Feminism in translation}

'Feminist translation' has been a growing term in translation studies in the last few decades. Luise von Flotow popularized it in her analysis of the work of Canadian feminist writers and translators to critique and alter the patriarchal language of canonical male authors and/or put forward gender issues in the text (von Flotow 1991, 1997). As Lori Chamberlain (1988) had warned, translation theory itself had been long permeated by gender-charged language with ideas such as fidelity, or translation as reproduction (feminine) vs. writing as creation (masculine). Scholar von Flotow broadly defined feminist translation as the endeavour by which female translators make their presence visible in the text, either by way of accompanying paratexts, or by direct intervention in the text. This was contextualized in the translation debate about the fact that "translations are not the same as the originals and can never be the same [...] they are always in the process of modifying, deferring and displacing the original" (Wallmach 2006: 2). Translation is a conscious action and it is inscribed in a context that shapes and in turn is shaped by the role that this translation is given in its target culture, for which a translator, above all other mediators, is determinant. Insomuch as translators make "deliberate choices about 
which writer to translate, which foreign idea and materials to disseminate" their work can be considered "activist," whether it be feminist activism or other type of social activism (von Flotow 2011: 4).

While von Flotow's seminal study excelled in the analysis of Québecois feminist translation, the contextual singularity of the case study made it difficult to export because translation strategies as explicit as the ones she studied are not easily found in other languages, countries and timeframes. Recent collections have sought to widen the field while dispelling the notion of feminist translation as a purely Western phenomenon (von Flotow and Farahzad 2017) and also advocating for embracing the "F-word" and its political implication (Castro and Ergun 2017: 3). In Spain there has been a steady interest in the field in the past few years (Castro 2009; Brufau Alvira 2011; Palacios 2014; Bengoechea 2014) with particularly branching into the study of Spanish feminist translators in history (Castro 2010; Simón Palmer 2010; Sánchez 2014; Romero López 2016), as the present study attempts. That last line of research pursues the feminist foremother metaphor, that in translation meant rescuing the lost voices of the translatresses (Simon 1996: 45), that is, women intellectuals "whose work unjustifiably lapsed into oblivion" (von Flotow 2005: 43) and analyzing to what extent they left a conscious handprint in their translations. This type of research entails evaluating the translations themselves and "all the conditions affecting the production, the publication, the dissemination, the reception, the lack of reception and the revival of the text," that is, considering them as artifacts of their time (von Flotow 2005: 46). Women often started translating because of the limitations of patriarchal social conventions that prevented them from spreading their own voices as creative authors (Woolf 1929/2011). ${ }^{6}$ Because translation was perceived as an ancillary art, a lesser sibling of writing, it was easier for women to venture into the literary realm by the back doors of translation "and contribute to the intellectual life of their period" (Federici 2011: 81); thus women were often reduced to the roles of "translators, editors, hostesses [...] interpreters" (Showalter 1985: 128). There are countless examples of women writers that started publishing translations or went back to translation when their texts were not accepted. María Lejárraga herself had to survive by translating after her exile to Argentina in the aftermath of the Civil War, when her creative texts were no longer accepted because of her political affiliation and the death of her husband who had provided her with a pseudonym (Aguilera Sastre 2012: 6).

All in all, by using the term 'feminist translation' in this article I aim to categorize my case study within a well-established tradition, implying that: (a) María Lejárraga is one of those women whose contribution has been disregarded; (b) She translated being conscious of the limitations that society imposed on her as a woman (hence the pseudonym); (c) She translated with a feminist intention (a will to transform the society she was living in); and (d) She consciously intervened in the text she translated, even more so, she manipulated Ibsen's play so that it was better understood in the target culture and its feminist message was more explicit to the audience (as long as it was permitted by the conventions of her time). I argue that her way of doing feminist translation meant womanhandling or feminizing the text, that is to say, making women and feminism concerns more visible in the text. 


\section{Feminist translation strategies}

For the purposes of this article, I take as my point of departure Andrew Chesterman's description of 'translation strategy.' In Memes of Translation (1997), he defined translation strategy as "explicitly textual manipulation, directly observed from the translation product itself, in comparison with the source text." This is used to "arrive at the best version they can think of," to overcome the difficulties that the source text presents in its rendition process into a target text (Chesterman 1997: 88-92). Moreover, I take it to include the addition of a contextual and paratexual layer, in tune with the social aspects of translations in their timeframe (von Flotow 2005: 46).

Feminist translation strategies have been defined as choices made "from a sociocritical standpoint" and which, when used in the text itself, "can reflect and draw attention to aspects of the source text which are new, or innovative, or deemed 'useful' for the new readership" (von Flotow 2011: 7). Von Flotow distinguished three main feminist interventionist translation strategies: 1) prefacing and footnoting; 2) complementing or explicitation (to make evident the suggested content); 3) hijacking or conscious alteration with a political aim (von Flotow 1997: 24). Barbara Godard referred to the process, which she herself had practiced as a literary translator, as "womanhandling the text." For Godard, womanhandling meant getting rid of the modest, invisible figure of the translator and replacing it with an active aim to participate in the creation of meaning, delighting in the manipulation of the text, and "immodestly" flaunting one's signature "in italics, footnotes, even in a preface" (Godard 1990: 50). The term womanhandling is used here with a slightly different meaning, insomuch as Lejárraga and other early translators did not flaunt their intervention, but instead hid it in what could be termed a Trojan horse cloak to hide from the patriarchal establishment. Nonetheless I am proposing to revive Godard's term for talking about feminist translation because its suggestive connotations of literal handling or manipulation help bring forth the idea of feminization of the text, of writing or highlighting the female, feminine and/or feminist in the translation endeavour.

Godard's womanhandling was inscribed as a form of rewriting, a broader concept than translation (adaptation, criticism and other forms of transnational mediation) that was popularized by the so-called 'manipulation school' of Translation Studies from the 1980s on. Rewriting entailed manipulation since "from the point of view of the target literature, all translation implies a degree of manipulation of the source text for a certain purpose" (Hermans 1985: 11), and manipulation itself is mandatory in all literature, because "works of literature exist to be made use of in one way or another" (Lefevere 1985: 217). Pascale Casanova in her World Republic of Letters (1999/2004) even claimed that in order for a work to be appreciated in its transnational reception, that is, to be "consecrated," that work needs be manipulated and appropriated "by the literary establishment for its own purposes" (Casanova 1999/2004: 163). Casanova used Ibsen's case as a an example of extreme manipulation in its reception period.

In line with this, I agree that "to translate is to invent, create, and often to betray" the source (Mezei 1989: 9) and that therefore feminist translation strategies should not be criticized, or indeed shunned as they often are (Bengoechea 2014), because they are not so different from ordinary translation strategies, as some researchers have argued (Leonardi and Taronna 2011). On the contrary, when analyzed histori- 
cally in their context, they help us comprehend the ways in which literature travelled through the European frontiers and bring to light the work of agents that had remained invisible. Coming back to the text in hand, these strategies illuminate how the influence of María Lejárraga and Gregorio Martínez Sierra on the development of feminist ideas in Spain was even greater than it is usually assessed (O'Connor 1987; Blanco 2003), and how they (or rather she) were aware of the potential benefits of manipulating such an important theatrical text as A Doll's House. I will discuss this further below making use of some instances of translation strategies that can be considered feminist in this translation by María Lejárraga, at textual, contexual and paratextual levels. I am considering the contextual and paratextual levels as feminist translation strategies because the three aspects are closely interwoven inasmuch as they are mutually dependent, based on the same intervention will and can be inscribed to the same purpose. Consequently, my aim is to demonstrate that these strategies demonstrate that there is a conscious will of intervention, an intervention with a particular purpose that ties together with the interpretation of the text that the translator wanted to pinpoint in her preface. I will only consider the strategies immediately preceding and surrounding the text; that is, those that were directly womanhandled or manipulated by the translator. Therefore, I do not analyze the broader reception in this article, such as the reviews or the places where this version was staged, because they were beyond her reach. A more detailed study constitutes the core of my dissertation (Muñiz 2018).

With a view to establishing clearly when and how the translator intervened in the text, it was necessary to first determine the translation's source, as this was an indirect translation (that is, not translating directly from Ibsen's Norwegian text). In doing so I am drawing from the conclusions of my previous article (Muñiz 2016a) where I proved that the source was Robert Farquharson Sharp's 1910 English translation ${ }^{7}$ by applying textual criticism strategies to the target text collated in comparison with the translated texts in several languages that were available at that time for the translator (French, Italian, Portuguese, Catalan, four different English ones). It is important to make this clear because in this article, for the sake of clarity and brevity, the Spanish version will be compared mainly with Sharp's English text, and also to two popular French and Spanish existing translations that help contextualize the feminist translator choices. This 1910 translation appeared within the popular Everyman library collection in a volume that included two other Ibsen translations by prominent feminist and socialist Eleanor Marx (1855-1898), who had participated in the first public reading of A Doll's House in England, and had written her own version in 1891, A Doll's House repaired (Dukore 1990). In my view, it would not be farfetched to speculate that Marx had left some partial translation of the play at her untimely death, with which Sharp (1864-1945), a librarian at the British Museum, may have worked - or at least, that Lejárraga became interested in that version by making the same assumption.

\subsection{Contextual level}

\subsubsection{Belonging}

One important element in feminist translation, as Santaemilia highlighted, is the fact that female translators often had a strong sense of sisterhood female sorority and 
awareness of their work in relation to that of other women (Santaemilia 2011: 65). I should point out that, in my understanding, this relates to the fact that their translations had a specific position in their target culture, be it because they were motivated by social circumstances or because they triggered certain reactions in it. In her research on female translators' networks in Silver Age Spain, Dolores Romero López stresses the importance of the mutual support and trust of those women in their translation and writing endeavors that weaved a protective web around their work (Romero López 2015: 196). In her discussion, she includes María Lejárraga as one of the translators that clearly belonged to an established group of Madrid-based feminists associated with the Lyceum Club Femenino, and some of them also to various feminist pro-suffrage associations of the late 1910s and 1920s. Therefore, it can be said that both Lejárraga as translator and the translated text itself belong to a community of feminist translation, and that sense of belonging supports my interpretation of Lejárraga's work on Ibsen being part of a wider feminist translation endeavor.

\subsubsection{Text selection}

As I have already mentioned, this is neither the first translation nor the first staging of A Doll's House in Spanish. The theatre company of Gregorio Martínez Sierra had a wide repertoire of very successful plays: written by the "author," by other Spanish authors, and by foreign authors (either translated by his wife or by other translators). Consequently, this play was not translated because it was a novelty or because the company needed more work or success. Instead I argue that there was a conscious will to translate that specific play in that specific timeframe that can be connected to the importance of the play within the world feminist movement - as well as Ibsen's growth as a world dramatist that made performing his plays a prospectively lucrative choice. Although Ibsen had denied that his play had a conscious feminist aim speaking instead of humanism (Templeton 1990: 110), the truth is that the text was appropriated with that interpretation in all of its transnational reception. Indeed, Nora has been widely interpreted as "an iconic representation of an emergent female subjectivity tied to modernity" and her demands became "a metaphor for demands by nineteenth century women for subjective freedoms enjoyed by men" (Holledge, Bollen, Helland and Tompkins 2016: 10). The most successful plays by Ibsen at an international level (A Doll's House, Hedda Gabler, Ghosts...) all deal with how nineteenth century women struggled to gain control of their own lives (Holledge and Tompkins 2000: 21). Hence, merely translating A Doll's House can on its own be a feminist activity, an act of translation activism. This is particularly true when considering that the translation was created because the translator perceived that the play was not sufficiently well known or well-translated in Spain, and that it dealt with a matter that was important in Spanish society at that time, as is mentioned in the preface (Lejárraga in Martínez Sierra 1917a: 14). One common feature of the network of Silver Age Spain female translators was their willingness to translate other women or men whose work contributed to the debate on women's position in modern society (Romero López 2015: 202). In that sense, we could consider Carmen de Burgos' translation (Sanchez 2014) of Möebius's 1900 treatise $^{8}$ on the mental inferiority of women or Emilia Pardo Bazán's translation of John Stuart Mill's The Subjugation of Women (1869)..$^{10}$ Furthermore, María Lejárraga's translation of one of the most discussed plays in the feminist movement, A Doll's House, contributed to that debate. 


\subsubsection{Place (of the staging)}

In the introduction, I mentioned that this translation was designed to be performed by Gregorio Martinez Sierra's theatre company, who at that time was based in the Eslava Theatre of Madrid, which he rented for the whole of 1916-1917 and the next few seasons. The Eslava Theatre was a very popular theatre among the bourgeoisie of the capital, and before Martinez Sierra's tenancy from 1916 on it had been mainly devoted to the lyrical genre (Checa Puerta 1998: 150), that is, opera and zarzuela, which were usually more successful in audience terms than spoken theatre because they constituted part of the socialite life. Hence, this was far from a small avant-garde theatre, where Ibsen's plays had usually been staged in Spain (Siguán 2003; Mobarak 2013) and abroad (Briens 2015). The place was, in the words of prominent feminist Margarita Nelken in her review ${ }^{11}$ of the performance: "the least Ibsenian theatre we could imagine, the one least fit to hear Ibsen's ideas." 12 This is because the usual audience consisted of "fat, respectable women" chaperoning "girls of marriageable age." This means that this was the kind of audience least likely to sympathize with Ibsen's ideas about women's right to their own agency, and therefore by watching and accepting the play the "audience underwent as big a change as Nora did" (see note 12). My interpretation is that the translator knew this, and that part of her intention was to present that content to people who were less likely to know or be interested in the vindication of the feminist movement: to teach feminism to the non-feminists, as we might say. Therefore, the feeding of certain content to a certain audience is per se a feminist intervention.

\subsection{Paratextual level}

\subsubsection{Titling}

Quite interestingly, during my initial research comparing different little-known editions and reading contemporaneous reviews I found that this new version was the first to be published or staged with the title Casa de muñecas (before, different titles coexisted: Casa de muñeca, Una casa de muñeca, Nora). Casa de muñecas is nonetheless the title that has been used ever since, including re-editions of previous translations that had a different title. Probably what the translator did was only set down a term that was already used in conversation in Spain. But it is not unreasonable to suppose a conscious will to change the title on the part of María Lejárraga, who had previously demonstrated her interest in more idiomatic title translations, namely with her famous Domando la tarasca $(1917)^{13}$ instead of the most widely used La fierecilla domada, to translate Shakespeare's The taming of the Shrew. ${ }^{14}$ The innovation in the title may not strike one as such to readers unaware of the subtle yet idiomatic differences between the singular casa de muñeca [house of doll] and the plural casa de muñecas [house of dolls]. In Spanish, casa de muñecas is an everyday term used for the well-known toy. The other Spanish titles do not explicitly point to that connection, nor does the original Norwegian as Ibsen claimed to have coined the word dukkehjem (Henrik Ibsen's Letters, quoted in Holledge, Bollen, et al. 2016: 4). The proper Norwegian term for the toy was dukkestue or dukkehus and the idiomatic use of the term dukkehjem can be attributed to Ibsen who could have been indeed playing with the concept of the children's game and the iteration of references to 
home throughout the play (Smidt 2000: 70). Therefore, the new title of Casa de muñecas can be interpreted as an attempt to speak and go towards the universal instead of the particular, that is, to extrapolate the specific case of Nora in her own singular dollhouse and thus highlight the connection with the many existing dollhouses in turn of the century Europe in which a similar experience is lived by women every day. As such, it could be interpreted as a feminist critical intervention pointing towards the gender imbalance in patriarchal homes where women are supposed to be eternal minors all their lives, subordinate to the wishes of their husbands and fathers, and therefore dolls, as Nora admonishes herself in the last scene of the third act.

\subsubsection{Prefacing}

Prefacing and footnoting are amongst the most common feminist translation interventions by which "feminist translation becomes an educational tool supported with scholarly research" (von Flotow 1991: 77). This type of intervention allows the translator to explain her position towards the play and the choices that were made, while commenting on the source and target contexts and trying to bridge them and bring them together for the recipient. Prefaces were quite commonly used by Spanish female translators of the period. Margarita Nelken (1930/2011: 188) in her pioneer feminist criticism study Las escritoras españolas [The Spanish female writers] already hinted at the fact that prefaces were often used by Spanish women translators in history as their only platform to express criticism about women's position in the establishment. In this case, although in the text there are no footnotes (which would be extremely rare in a stage translation of the period) the edited edition is accompanied by a 2500 -word preface. Interestingly, this preface reproduces a speech that was given by the director of the play, Gregorio Martínez Sierra, just before the performance (like all the Martinez Sierra's feminist texts, I consider the intellectual author to be María Lejárraga). We do not know if this speech was given in every performance, or was only given at the premiere. The speech pinpoints the clear didactic message and will of intervention of the mediators (translator and writer of the speech, director and reader of the speech) in the interpretation of the play they wanted to transmit. The fact that the speech was given before the performance is an ideological standpoint in itself. A few months before Martínez Sierra had used the same stage to give a presentation about the development of feminism (later included in Feminismo, feminidad, españolismo) which concluded with the words that "all women must be feminists by the law of nature” (Martínez Sierra 1917b: 43). This is a clear example of the feminist activist attitude that had characterized the theatrical season in which the new translation of $A$ Doll's House was introduced, which reinforces the contextual strategy previously called 'belonging.'

In the speech-preface there is a very thorough ideological explanation of the meaning of the play according to the translator. This is done by providing information about the plot (the fact that the play carries a feminist message is highlighted and dissected throughout the preface), explaining why it was important to have this play translated again at this moment in Spain, and how the translator has approached the task of translating. It is clear that the intention of this translation was not to surprise the audience (which would be the thing to do for commercial purposes) because it anticipated and even spoilt the climax of the play, Nora's door-slamming. 
In the second paragraph, it already stated that the play was about a woman facing her husband and claiming to be a human being with the same rights and duties. While the translation of that dialogue within Act III was rather almost word for word, in this preface the translator allowed herself to continue Nora's thoughts which are verbalized as follows:

¡Yo soy yo! Pero no valgo lo que debiera. Por vivir para otros he olvidado mi alma, he descuidado mis deberes para conmigo misma... casi no me conozco ¡voy a buscarme! Casi no existo, tan ignorante soy de la vida, tan irresponsable, tan inconsciente. Voy a educarme, voy a procurar aprender lo que ignoro, comprender lo que nunca he sospechado. (Lejárraga in Martínez Sierra 1917a: 11)

[This is me! But I am not worth as much as I should be. By living for the sake of others I have forgotten my soul, I have neglected my duties to myself... I barely know myself. I have to go and find myself! I almost do not exist, I am so ignorant of life, so irresponsible, so unconscious. I am going to educate myself, I am going to try to learn what I do not know, to understand what I never suspected]. (my translation)

By putting words in Nora's mouth that Ibsen never wrote, María Lejárraga was asserting her right to appropriate the character, flaunting her role as creator beyond translator; by engaging creatively with the text, she was seeking to steer the interpretation of the play towards the aspects she thought should be emphasized so the audience would grasp them. After that first-person appropriation, the translator went on to dissect the meaning of that moment (referred to as "thesis of the play" in that speech) in social and feminist terms, boldly tackling such complex concepts as the notion of patriarchy and the traditional gender roles that were associated with it:

Porque todos los viejos fundamentos patriarcales de la familia -dominación absoluta del varón, sumisión incondicional de la hembra - se desmoronan en cuanto se afirme que el deber de la esposa no consiste en vivir para el hombre sino con el hombre, en igualdad de soberanía y responsabilidad, que sus obligaciones no están condicionadas más allá que por su propia conciencia, que la ley de su vida no ha de venirle del marido, sino de la suprema justicia, a la cual han de estar los dos sujetos por iguales sanciones y con la misma estricta obligación. (Lejárraga in Martínez Sierra 1917a: 12)

[Because all the old patriarchal foundations of the family - complete domination of the man, unconditional submission of the woman - crumble as soon as it is stated that the duty of a wife is not to live for a man, but with a man, with equal responsibility and sovereignty, that her duties are not determined any further than what her conscience dictates, and that the law of life must not come from her husband, but from supreme justice, to which both must be subjected, with equal sanctions and equally strict obligation]. (my translation, emphasis in the original)

The speech-preface continued the argument for over a thousand words more, explaining the scandal that the play produced in various places and how it was quickly linked to the feminist movement, Ibsen's position of denial towards feminism (despite what she thinks is a clear positive attitude in the text) and Ibsen's development as a dramatist. It also explained how this translation compared with other previous Spanish translations and made clear that unlike the others, this was "an absolutely literal translation" with only "two or three very light cuts" that do not intend to "alter consciously the original meaning" because "translators should not impose their will on another's work"15 - a guideline that was not followed on this translation. On the contrary, as explained throughout this article, there is a clear willingness to alter or condition the way the play would be interpreted by the 
audience by taking and emphasizing a certain part of the original message already emphasized in the first lines of the preface, into the final scene of the play. Thus the didactic aim of the speech is blatant. This disposition towards manipulation continues in the translated text where there are indeed more than two or three cuttings, some of them elucidated below.

\subsection{Textual level}

The practice of feminist translation and/or rewriting has been controversial (Hermans 2009: 100) insomuch as it is a potentially unethical interventionism that explicitly alters the text and hence the interpretation thereof. In eliminating content, the translator comes closer to censorship, while when adding content, the translator is creating (changing the punctuation and some words to make the meaning clearer), that is, not only visibilizing the work of the translator in Venutian terms, but also claiming authorship. Nonetheless, it is naive to presuppose that there is a way of translating that does not constitute rewriting, that does not involve manipulation to a greater or lesser extent. Disregarding feminist translation for its open interventionism comes dangerously close to prescriptiveness, that is, preaching on what is good or bad translation in terms of fidelity, a term that is especially polemical for feminist translation scholars (Chamberlain 1988). Translations are texts in their own right, and all translators perform a varying degree of rewriting in their translation. The main difference is that feminist translation strategies are following a political agenda in order to correct the source text and make explicit one given interpretation thereof, or in Luise von Flotow's terms, they actively hijack the text.

While it may be an anachronism to say that Lejárraga was hijacking the text, she seemed willing to actively modify it in order to project a specific interpretation of the play and to make explicit some feminist ideas that were only implicit in the source text. This was executed essentially by rewriting most of the dialogues of the play in a threefold manner: (a) the whole play is shorter and deprived as much as possible of inane conversation exchanged (eliminating one sentence dialogue lines and condensing others) and superfluous information (that is, information that is not relevant to the "thesis" of the play); (b) misogynistic comments are downplayed throughout the play; (c) Nora's dialogues are subtly changed in tone to highlight Nora's acquisition of agency, increasingly so as the play advances (in contrast with Helmer's more paternalistic tone at the beginning that is diluted throughout). In this article there are analyses of these three. The majority of these changes take place in the third act (which is twenty percent shorter than the English source and the Norwegian original). This is not surprising since the translator hinted in the speech-preface that the last part condenses the "thesis" of the play. For that reason, the translator's intervention was ubiquitous in the last dialogue between the spouses insomuch as it aimed to shape with surgical precision the wording of the speech by highlighting the feminist aspects.

Having analyzed the whole play line by line, I have been able to isolate examples of translation changes that can be interpreted as feminist throughout the play. In my dissertation (Muñiz 2018) I present a thorough analysis of those changes, but for the sake of brevity and clarity this article only includes the most outstanding examples that demonstrate my hypothesis. Those are clear translation shifts that omit or 
modify certain key phrases, always in connection with gender-sensitive content that the translator willingly sought to alter. In order to contextualize those translation changes, Lejárraga's translation will be compared not only to the source (Norwegian) or the intermediary translation (Sharp's 1910 English translation for the Everyman library) (Muñiz 2016a) but to the two most easily accessible translations in Spain at that time: the anonymous first Spanish translation (penned by the intellectual José de Caso) (Muñiz 2016b) from 1892, a text that was widely reutilized in several editions in the period $(1902,1916,1926,1931)$ (Muñiz 2018), and the popular 1889 French translation ${ }^{16}$ by Count Prozor, that was the gateway to Ibsen for most of Romancespeaking Europe, as French continued being the language of culture for intellectuals, and the preferred intermediary source for translations (it was the source for the 1892 Spanish translation). Comparing Lejárraga's text with those alternative translations emphasizes the singularity of Lejárraga's feminist translation choices.

\subsubsection{Reducing paternalistic dismissals of women}

This first example is extracted from the very first scene of the first act, when Nora and Helmer are talking about money and Helmer responds to her suggestion of borrowing money with one of the most quoted lines of the play: Du est en kvinde! (You are a woman!) (Ibsen 1879/2008: 216, my translation). Helmer's dismissal of his wife and by essentialist extension all women epitomises his treatment of Nora as a childish scatterbrain throughout most of the play and foreshadows the theme of the misunderstanding of men and women within marriage.

1) Nora, Nora, du est en kvinde! Nej, men alvorligt, Nora.

(Ibsen 1879/2008: 216; see note 2)

a) Nora, Nora, you are a mere baby. But seriously, dear child...

(Ibsen 1879/1882: 4, translated by Henriette Frances Lord) ${ }^{17}$

b) Nora, Nora! What a woman you are! But seriously, Nora.

(Ibsen 1879/1889b: 4, translated by William Archer; see note 3)

c) That is like a woman! But seriously, Nora.

(Ibsen 1879/1910: 6, translated by Robert Farquharson Sharp; see note 7)

d) Nora, Nora, tu es une vraie femme. Sérieusement, Nora...

(Ibsen 1879/1889a: 154, translated by Count Prozor; see note 16)

e) Nora, Nora, eres una verdadera mujer. En serio, Nora.

(Ibsen 1879/1892: 132, translated by José de Caso; see note 4) (Muñiz 2016b)

e) (omission) En serio, Nora.

(Ibsen 1979/1917: 33, translated by María Lejárraga de Martínez Sierra; see note 1 )

The early translations of this fragment are particularly interesting. As JensMorten Hanssen (2010) has pointed out, the Norwegian contains both reproach and a sense of pride, whereas in translation this often becomes merely a reproach: "You are only a woman," "You are but a woman," "You are indeed a woman," "You are a true woman" - in Chinese, it even becomes "Nora, you are so ignorant" (Hanssen 2010). Indeed, in most English translations the text is very reproachful, hinting at the negative aspects of being a woman, and by extension insulting all women (in the French translation the reproach is framed by the adjective vraie or true, that paradoxically 
hints positive connotations while the demeaning undertone remains). The exception is the translation by Henrietta Frances Lord, a feminist herself, who sought to attenuate the insult by changing it to a mere baby, so that the reproach implies that Nora's defects are because she was childish, not because she was a woman. But quite interestingly, María Lejárraga omits completely that phrase when she could have written a translation such as the conversational turn-of-phrase "¡Mujer tenías que ser!" [You had to be a woman!] that would have rendered the meaning in the very idiomatic fashion that is present in other phrasing rewritings in the play. In my interpretation, this is because she wanted to avoid insulting the whole female gender, that is, an essentialist view, as if all women could be judged on the same terms, and also based on the complicit understanding that they all share a common fault. Thus, she is womanhandling the translation by reducing some of the paternalistic remarks of the text.

\subsubsection{Avoiding indoctrination about gender roles}

The next example comes from the final dialogue when Nora announced that she wanted to leave, and Helmer was trying to convince her that she must not. Nora said that she had felt treated like a doll, first in the hands of her father and now in the hands of her husband, and Helmer acknowledged that there was truth in her words, but that playtime is over and that she must now educate herself. Nora rebuked his paternalistic offering: du er ikke mand for at opdrage mig til en ret hustru for di (You are not (the) man to instruct me to (being) a right wife for you) (Ibsen 1879/2008: 368, my translation). In doing so, while she had acknowledged her need of education, she is not only rejecting his help, but also implying that he himself was in need of education as he is not the right man to educate her.

2) Ak, Torvald, du er ikke mand for at opdrage mig til en ret hustru for di.

(Ibsen 1879/2008: 368)

a) Hélas! Torvald, tu n'es pas homme à m'élever pour l'aire de moi la véritable épouse qu'il te faut.

(Ibsen 1879/1889a: 271, translated by Count Prozor)

b) ¡Ay, Torvaldo! No eres tú hombre para educarme, para hacer de mí la verdadera esposa que necesitas.

(Ibsen 1879/1892: 161, translated by José de Caso)

c) Alas, Torvald, you are not the man to educate me into being a proper wife for you.

(Ibsen 1879/1910: 81, translated by Robert Farquharson Sharp)

d) ¡Ay, Torvaldo, tú no eres hombre capaz de educarme!

(Ibsen 1879/1917: 222, translated by María Lejárraga de Martínez Sierra)

The English and French translations reproduced the statement that Nora's education is about how to be a proper wife, as did the existing Spanish translation. But in Lejárraga's translation of Nora's reply the second part of the phrase was omitted so that it made no reference to the idea that there is a way of educating women on how to be a proper wife. Therefore, what she acknowledged is her need for education in general, not education to be a wife. By eliminating that reference, the translator is making a stand against the nineteenth-century domesticity politics in which the role of a woman was primarily being a wife, and particularly against the implication that 
this role required indoctrinating women into the submissiveness expected of wives. Lejárraga's omission echoes in absentia the famous speech of the Spanish feminist author Emilia Pardo Bazán: female education was a "taming” process, insomuch as its main aim was not knowledge but to obtain "full obedience, passivity, and submission" (Pardo Bazán 1892/1999: 164).

This example and the following three I cite come from the dialogue exchange after Nora declares she is a human being just like Helmer is. That key moment of the play is rendered almost word for word (and referred to also in the speech-preface), with the exception of the reference to religion that is omitted, most likely because of self-censorship in order to avoid scandal - references to blasphemous ideas (sex, religion or politics) were often eliminated in translation practices (Crespo 2007: 54). This, along with Helmer's lines while Nora is changing her dress (she does not change dress in the Spanish version) are the longest omissions in the play.

\subsubsection{Rejecting the universal masculine and awareness of legal concepts}

The next example comes several lines later - Nora continued talking about the idea of getting a proper education for herself and two small changes are included in the conversation. In the original and all the other translations, the character made reference to Helmer not being "the man" to help her (Det er du ikke mand for) (Ibsen 1879/2008: 368), that is, that he is not adequate but implying that maybe another man could be better fitted for the task. In other words, that the possibility of helping her, of educating her, can be found in a man; that knowledge itself is in the hands of men. Of course, this use of the noun "man" may be simply an example of universal masculine. The use of the universal masculine to refer to the whole humanity is pervasive in language as criticized by feminist linguists, and one of the common points of feminist translation is to make the language more feminine or at least inclusive. Nonetheless, awareness of how the universal masculine in language renders women invisible de facto arose long before. For example, the French Revolution activist Olympe de Gouges had pointed out that the Déclaration des droits de l'homme et du citoyen $(1789 / 1791)^{18}$ did indeed only refer to men, and not to women, and proposed her own Déclaration des droits de la femme et de la citoyenne $(1791)^{19}$ to make women's rights visible. While all the translations examined reproduced the universal masculine, in Lejárraga's Spanish text, that reference was changed to the gender-less second person singular pronoun tú [you].

3) Der er en anden opgave, som må løses først. Jeg må se at opdrage mig selv. Det er du ikke mand for at hjælpe mig med. Det må jeg være alene om. Og derfor rejser jeg nu fra dig.

(Ibsen 1879/2008: 368)

a. Il en est une autre dont je dois m'acquitter d'abord. Je veux songer avant tout à m'élever moi-même. Tu n'es pas homme à me faciliter cette tâche. Je dois l'entreprendre seule. Voilà pourquoi je vais te quitter.

(Ibsen 1879/1889a: 271, translated by Count Prozor)

b. Hay otra que debo atender desde luego. Quiero pensar, ante todo, en educarme a mí misma. Tú no eres hombre para facilitarme ese trabajo. Tengo que emprenderlo yo sola. Por eso voy a dejarte.

(Ibsen 1879/1892: 161, translated by José de Caso) 
c. There is another task I must undertake first. I must try and educate myself--you are not the man to help me in that. I must do that for myself. And that is why I am going to leave you now.

(Ibsen 1879/1910: 81, translated by Robert Farquharson Sharp)

d. Primero tengo que educarme a mí misma... y tú no puedes ayudarme. Tengo que conseguirlo yo solita. Por eso, precisamente, me separo de ti.

(Ibsen 1879/1917: 223, translated by María Lejárraga de Martínez Sierra)

Further on in the next line må jeg være alene [I must be alone], Lejárraga's translation made a tone shift marked by the colloquial turn-of-phrase yo solita [I alone/ on my own] that acquires an emphatic meaning due to the use of the first-person pronoun (not grammatically necessary in Spanish) and the diminutive (that may have a sarcastic connotation in Spanish). In the last line there is another significant change. In Norwegian, she rejser, that, is, she goes away (not specifically with the idea of breaking up, of leaving him), which in Spanish would be me marcho or me voy. But in the translations, there is a further significance - the French, the anonymous Spanish and the English all include the idea of leaving him, that is to say, of breaking up the relationship and leaving the conjugal home. Leaving the conjugal home, stopping cohabitation without taking proper legal measures is still considered a legal breech in many countries' legislations, and it was indeed in Spain up to the end of Francoism. Lejárraga chose to translate it as 'separate' instead of 'leave' which recalls the process of 'separation', similar but not exactly the same as a divorce, which was not legal in Spain until 1932.

\subsubsection{Reinforcing agency}

The next example is from just a few lines after the previous one, when Nora said that she would go back to her old home to find something to do there. The question of what precisely Nora would do after she left her husband has been the subject of thousands of conversations, articles and literary works since the late nineteenth century.

4) Imorgen rejser jeg hjem, - jeg mener, til mit gamle hjemsted. Der vil det være lettest for mig at komme ind i et eller andet.

(Ibsen 1879/2008: 369)

a) Demain je pars pour chez moi; je parle de mon pays d'origine... J'y trouverai plus facilement à vivre.

(Ibsen 1879/1889a: 272, translated by Count Prozor)

b) Mañana salgo para mi país. Allí podré vivir más fácilmente.

(Ibsen 1879/1892: 161, translated by José de Caso)

c. Tomorrow I shall go home-I mean to my old home. It will be easiest for me to find something to do there.

(Ibsen 1879/1910: 81-82, translated by Robert Farquharson Sharp)

d. Mañana me marcho a mi casa... quiero decir a mi casa de soltera. En mi pueblo me será más fácil encontrar modo de ganarme la vida.

(Ibsen 1879/1917: 224, translated by María Lejárraga de Martínez Sierra)

In the Norwegian text and the English translation, Nora was simply parting ways to do "something" imprecise (ind i et eller andet). The French translation and the Spanish anonymous one were even less determined because Nora did not claim to intend to do something, however imprecise, but instead she just hoped to be able to 
live easily, which implied external aid. In Lejárraga's version, Nora claimed instead that she was going away to find a job to support herself (ganarme la vida [earn her own living]). In Spanish, there was no room for doubt: she would take charge of her life economically speaking. The French and the first Spanish translations also entail a mistranslation, since mon pays d'origine/ mi país [homeland] imply Nora is a foreigner, when she was not, she referred to her hometown (hjemsted), mi casa de soltera/ mi pueblo in Lejárraga.

\subsubsection{Avoiding submissiveness}

The following example, again from one of Nora's dialogue lines, illustrates well how her discourse had been growing since her awakening in the key scene where she had stated: jeg er først og fremst et menneske (I am first and foremost a human being) (Ibsen 1879/2008: 370, my translation). She was no longer using childlike language or demeaning herself - she was well aware that she was a grown woman and that she had full control of her life choices. While this strengthening is present in all translations, there is a tone difference that makes Lejárraga's translation stand out from the rest.

5) Lad gå. Men du hverken tænker eller taler som den mand, jeg skal kunne slutte mig til.

(Ibsen 1879/2008: 369)

a) Admettons. Mais tu ne penses pas, toi, et tu ne parles pas comme l'homme qu'il me serait possible de suivre.

(Ibsen 1879/1889a: 276, translated by Count Prozor)

b) Démoslo de barato. Pero tú no piensas ni hablas como un hombre a quien yo pueda seguir.

(Ibsen 1879/1892: 163, translated by José de Caso)

c. Maybe. But you neither think nor talk like the man I could bind myself to.

(Ibsen 1879/1910: 84, translated by Robert Farquharson Sharp)

d. Puede; pero tú no hablas ni piensas como el hombre a quien yo creía querer.

(Ibsen 1879/1917: 230, translated by María Lejárraga de Martínez Sierra)

Indeed, instead of talking of the man that she could bind [her] self to or follow, that is, acquire a submissive position, she talked of the man that she creía querer [she thought she loved]. She was speaking of a relationship in equal terms, based on love and respect and not on the submission of one gender to the other. In the original Norwegian, slutte meg til [join] is not as submissive as the English (bind) and French (suivre) - meaning agree with, be joint with, implying to a certain extent an equality between the sexes. But Lejárraga went beyond that and established that the basis of the relationship between husband and wife must be mutual love, not a hierarchy, not even a legal agreement. If we remember the quotation from the preface, she had already insisted that the "duty of a wife is not to live for a man, but with a man, with equal responsibility and sovereignty” (Lejárraga in Martínez Sierra 1917a: 12; my translation). This idea appeared often in her essays - for example in Nuevas Cartas a las mujeres de España (1932). ${ }^{20}$ This example works well as the closing example because it sums up the ideas that we already explained throughout this article. Through the feminist translation shift Nora's speech is more determined and powerful; while being more conversational, it is also making a stand about the gender roles and illustrates how the translator rejects to follow the conventions expected of women. 
All in all, and as I have attempted to capture and explain through these examples, Lejárraga's Spanish Nora sounded more decisive and empowered, more aggressive and sometimes even blunt, less hesitant and docile, and more aware of her capacity to decide as an individual. She was also very aware of the kind of marriage she wanted to have, making explicit what was only suggested in the original but, most importantly, subverting or hijacking some of the content of the original that reproduced an idea of marriage in which the wife is submissive to the husband. With all these translation shifts, the translator was highlighting the growth of the character and also taking a stand, teaching a lesson to the audience about the roles of men and women in marriage. The discussion of these examples of textual alterations supports my hypothesis that the feminist translation strategies were applied in order to foment a specific interpretation of the play and highlight the feminist message that was explained in the speech-preface. The translator was willing to hijack Ibsen's text so that the message was more explicitly feminist. Those translation strategies were not merely modifications at textual level but found a correlation with the interventions done at paratexual and contextual level, making the feminist translation a cohesive transversal work.

\section{Conclusion}

The starting point of this article was the reassessment of the importance of María Lejárraga's forgotten retranslation of Ibsen's A Doll's House. As I mentioned at the beginning, this Spanish translations stands out for several reasons: for being the only version staged in Spain throughout the period 1917-1936, for having been published under a false name that shadowed the intervention of a feminist translator (arguably, making it thus more effective as a Trojan horse technique), and for being textually rather different from the other available versions in Spanish (due to the fact that it was shorter, and its main intermediary source had been English and not French); these differences entailed, as we have pointed out, significant politically-charged textual manipulations that make the translation a rara avis amongst the early translations of Ibsen's plays. Besides, given the (overt) feminist political affiliation of the (covert) translator and the feminist interpretation that the text has received throughout its reception history, I considered this case study an interesting testing ground for determining to what extent it is possible to find feminist translation strategies in texts from the early twentieth century, from the first wave of feminism, that is, long before feminist translation was conceptualized and openly put into practice in the last decades of the twentieth century.

This case study also attempted to cover a knowledge gap within two areas: (gender) translation research in Spain, and Ibsen studies in relation to feminism and translation. Although significant attempts to apply the concept of feminist translation to Spanish translation practices have been made, there had previously been no study relating to the significant role of María Lejárraga as a feminist translation, insomuch as her translation career of over fifty years has been mostly ignored by translation scholars. On the other hand, although the question of to what extent Ibsen's A Doll's House can indeed be considered as a feminist text has been researched, there have been no studies from a translation research perspective, showing specifically how/if that feminist intentionality was translated in the target culture by the intervention 
of the translator. While recent research has brought the light the importance of women, particularly actresses, as mediators of Ibsen in the early reception (Holledge, Helland, et al. 2016) there have been no previous studies of the feminist mediator as a translator, as this article does.

In accordance with my aims, I have argued how María Lejárraga’s 1917 translation can indeed be considered a valid example of early feminist translation strategies applied to a text that was key in the development of feminist ideas in the last century. In my analysis of the feminist translation strategies I have made critical use of Luise von Flotow's well-known categories and complemented them with my own threefold division of interventions (in context, paratext and text) that has proven useful for unbinding the manifold feminist intervention that had been artfully concealed in the translation process. The overall conclusion of my example discussion highlights that the feminist translation strategies were used with one unifying didactic aim that could be perceived already in the speech-preface by the continuous focus on what the translator considered the thesis of the play: that is, that by putting emphasis on the last scene between Nora and Helmer, the translator brings attention to the gender inequalities of marriage, and to the necessity that women are both aware of this and have a will for the acquisition of agency and emancipation. All the decisions and alterations analyzed here were performed to highlight that moment and make sure it was correctly perceived and internalized by the widest array of audiences.

Overall, this translation can be considered a successful, if intriguing, attempt by Lejárraga to feminize and to some extent domesticate the play with an agenda of her own. This agenda is based on the translator's own specific understanding of what was necessary in Spain to introduce and mainstream feminist ideals (which would be in tune with the repertoire of proto-feminist plays she wrote) by using a text that was perceived as feminist in its international reception. Even so, this conclusion raises more questions. The alterations performed on the target text may be considered as a simplification of the message of the source text, which could be interpreted from the didactic aim of the translator. Beyond the educative intention that presupposes a fragmentation and explication of potentially complex elements one wonders to what extent it is possible to balance activism in translation with an almost patronizing approach in which certain elements are highlighted or downplayed so that the spectator is fed one arguably simplified or at least less nuanced play. While it would be difficult to measure the effect of the feminist message the mediators wanted to spread with the translation, in terms of how much they influenced the perception of feminism of the audience, the intervention doubtless contributed to the success of the play in marketing terms.

It may be possible to dispute the leading argument of this article by signalling the fact that the translator published her work under a male name, and to thus argue that she was not willing to visibilize her position as a conscious and willing agent in the reception context, which therefore implies that she was not indeed a feminist because she was conforming to gender expectations of female submissiveness. While I acknowledge that this counter-argument can indeed be raised, I think the willing invisibility of the translator in the public sphere does not invalidate the importance of her intervention in the text, nor does it contradict her intentions to make the thesis of the play known in Spain in order that a certain debate be held. Besides, this argument has been used and confronted before in the assessment of María Lejárraga 
as one of the foremothers of Spanish feminism, concluding that she used a male name because she considered it the best way of broadly penetrating the target culture at that particular moment from a position of authority that very few, if any, women were given at that time (Blanco 2003). Furthermore, the actual extent of María Lejárraga's feminist womanhandling in the translation of $A$ Doll's House brought to light in this article accentuates her feminist activism and reinforces the interest of researching the activities of the feminist translator network of Silver Age Spain. Therefore, I consider that re-assessing historical translations by female translators under these critical lenses may be a fruitful path to follow in future research. Bringing to light the feminist mediation or womanhandling of past female translators would strengthen our understanding of translation history and its relation to the history of women and of feminism, since translation was for centuries the intellectual activity that many women intellectuals could more easily engage with, notwithstanding the invisibility of their task.

\section{ACKNOWLEDGEMENTS}

Early, example-driven and complementary versions of this paper were orally presented at the following seminars: Gender, Translation and Transnational Reception (Oslo, 12-13 November 2015): "María Lejárraga and the (re)introduction of Ibsen's Et Dukkehjem in Spain. Between domestication and a feminist campaign"; Ibsen in the world (Oslo, 2-3 June 2016): "The feminist writer translates: María Lejárraga's work on Et Dukkehjem - Casa de muñecas, 1917.” Both seminars were organized and funded by the research group Traveling Texts: Translation and Transnational Reception (http://www.hf.uio.no/english/research/theme/traveling-texts/).

\section{NOTES}

1. Ibsen, Henrik (1879/1917): Casa de muñecas. (Translated by Gregorio Martínez Sierra [María LejÁRRAGA]) Madrid: Renacimiento.

2. IbSen, Henrik (1879/2008): Et dukkehjem [A doll's house]. In: Christian Janss, Hilde BøE, Stine Brenna TaugbøL, Narve Fulsås, and Vigdis Ystad, eds. Henrik Ibsens skrifter [Henrik Ibsen's writings]. Vol. 7. Oslo: Aschehoug, 211-379.

3. IbSen, Henrik (1879/1889b): A Doll's House. (Translated by William Archer) London: Fisher Unwin.

4. Published in two parts: Ibsen, Henrik (1879/1892): Casa de muñeca. (Translated by José DE CAso) La España Moderna. 43:131-170.

IbSEN, Henrik (1879/1892): Casa de muñeca: conclusión. (Translated by José DE CAso) La España Moderna. 44:150-165.

5. This was demonstrated by studying manuscripts and letters that proved that most of the works published under the husband's name were written by her (O’Connor 1987), although Lejárraga always preferred to speak of "collaboration" (Martínez Sierra 1953/2000: 73), a kind of collaboration in which she was in charge of the private sphere (writing, correcting) and he was in charge of the public (editing, directing, managing).

6. Woolf, Virginia (1929/2011): A Room of One's Own. Three Guineas. London: Penguin.

7. Ibsen, Henrik (1869/1910): A Doll's House. In: Henrik IbSen. A Doll's House and two other plays. (Translated by Robert Farquharson SHARP) London/New York: Dent/Dutton, 5-86.

8. MöвiUs, Paul Julius (1900): Über den physiologischen Schwachsinn des Weibes [About the psychological nonsense of the woman]. Halle: Marhold.

9. Mill, John Stuart (1869/1892): La esclavitud femenina. (Translated by Emilia PARdo BAzÁN) Biblioteca de la Mujer. Vol. II. Madrid: Administración.

10. Mill, John Stuart (1869): The Subjugation of Women. London: Longmans, Green, Reader, and Dyer.

11. Nelken, Margarita (10 May 1917): La vida y las mujeres. A propósito de Casa de muñecas. El día. 38(13335):3. Visited on 19 June 2018, <http://hemerotecadigital.bne.es/issue.vm?id=0003476917\& search=\&lang=en $>$. 
12. Eslava es precisamente el teatro que podíamos imaginarnos menos ibseniano, menos a propósito para escuchar en él las ideas de Ibsen. Es el teatro que nos figurábamos como más tranquilo, el más moral usual, en una palabra, el teatro burgués por excelencia (...) Y es en el Eslava, ante el público del Eslava, donde Nora se atreve a declarar que antes que nada es un ser humano. ¿Cuál de estas niñas casaderas o jamonas respetables que van al Eslava pensó jamás semejante cosa? (...) Puede decirse que una transformación tan grande como la de Nora la ha tenido el público que la aplaude. (see note 11; my translation)

13. Shakespeare, William (1623/1917): Domando la tarasca. (Translated by Gregorio Martínez Sierra [María Lejárraga]) Madrid: Clásica Española.

14. Shakespeare, William (1623): The Taming of the Shrew. In: William Shakespeare. Mr. William Shakespeare's Comedies, Histories, \& Tragedies. London: Edward Blount, William Jaggard, and Isaac Jaggard.

15. Hoy van ustedes a oír, no una adaptación, sino una traducción absolutamente literal de la obra. Para la representación nos hemos permitido hacer dos o tres ligerísimos cortes, que en nada alteran el pensamiento ni el proceso psicológico. Eso es todo. No hay una sola palabra alterada, trocada ni desviada a sabiendas de su sentido original. Yo creo firmemente que un traductor no tiene derecho a imponer su criterio personal en labor ajena. (Lejárraga in Martínez Sierra 1917a: 15-16; my translation)

16. IbSEn, Henrik (1879/1889a): Maison de Poupée. (Translated by Maurice Prozor) In: Maurice Prozor, trad. Théâtre: Les Revenants, Maison de Poupée. Paris: Albert Savine, 149-279.

17. Ibsen, Henrik (1879/1882): Nora. A Play. (Translated by Henrietta Frances Lord) London: Griffith and Farran.

18. Champion de Cicé, Jérôme (1789/1791): Déclaration des droits de l'homme et du citoyen. In: Assemblée constituante de 1789. Constitution française du 3 septembre 1791. Paris: Imprimerie nationale, 1-8.

19. Gouges, Olympe de (1791): Déclaration des droits de la femme et de la citoyenne. In: Olympe de Gouges. Les droits de la femme. À la Reine. Paris, 5-24.

20. Martínez Sierra, Gregorio [María Lejárraga] (1932): Nuevas cartas a las mujeres de España. Madrid: Renacimiento.

\section{REFERENCES}

Aguilera Sastre, Juan (2012): María Martínez Sierra, traductora: una lectura de teatro contemporáneo. Anales de la Literatura Española Contemporánea. 37(2):9-36.

Aguilera Sastre, Juan (2014): Feminismo y teatro: Los Martínez Sierra ante Casa de muñecas. Anales de la Literatura Española Contemporánea. 39(2):5-37.

Aguilera SAStre, Juan (2016): María Martínez Sierra (1874-1974): El noble oficio de la traducción. In: Dolores Romero López, ed. Retratos de traductoras en la Edad de Plata. Madrid: Escolar y Mayo. 59-86.

BengoecheA, Mercedes (2014): Feminist translation? No way! Spanish specialised translators' disinterest in feminist translation. Women's Studies International Forum. 24:94-103.

Blanco, Alda (2003): A las mujeres: ensayos feministas de María Martínez Sierra. Logroño: Instituto de Estudios Riojanos.

Brufau Alvira, Nuria (2011): Traducción y Género: El estado de la cuestión en España. MonTI. 3:181-207.

BrIENS, Sylvain (2015): La mondialisation du théâtre nordique à la fin du XIX ${ }^{\mathrm{e}}$ siècle. Le fonds Prozor de la Bibliothèque nordique de Paris lu au prisme de la sociologie de l'acteur-réseau. Revue de Littérature comparée. 354:137-150.

Casanova, Pascale (1999/2004): The World Republic of Letters. (Translated by Malcolm DeBevoise) Cambridge: Harvard University Press.

CAstro, Olga (2009): Reexaminando horizontes en los estudios feministas de la traducción: ¿hacia una tercera ola? MonTI. 3:59-86.

Castro, Olga (2010): Tradución, Xénero, Nación: Cara una Teoría e Práctica da Traducción. Doctoral dissertation, unpublished. Vigo: Universidade de Vigo.

Castro, Olga and Ergun, Emek (2017): Introduction. Re-Envisioning Feminist Translation Studies: Feminisms in Translations, Translations in Feminism. In: Olga CAsTro and Emek 
Ergun, eds. Feminist Translation Studies: Local and Transnational Perspectives. New York: Routledge, 1-11.

Chamberlain, Lori (1988): Gender and the Metaphorics of Translation. Signs. 13(3):454-472.

Chang, Shuei-may (2004): Casting off the Shackles of Family: Ibsen's Nora figure in Modern Chinese Literature (1918-1942). New York: Peter Lang.

Checa Puerta, Julio Enrique (1998): Los teatros de Gregorio Martínez Sierra. Madrid: Fundación Universitaria española.

Chesterman, Andrew (1997): Memes of Translation. Amsterdam: John Benjamins.

Crespo, Juan (2007): Políticas de traducción en las Españas del siglo XIX. In: Juan Jesús ZAro, ed. Traductores y Traducciones de Literatura y Ensayo (1835-1919). Granada: Comares, 45-72.

Dukore, Bernard (1990): Karl Marx's Youngest Daughter and A Doll's House. Theatre Journal. 42(3):308-321.

Farfan, Penny (1996): From "Hedda Gabler" to “votes for Women”: Elizabeth Robins's Early Feminist Critique of Ibsen. Theatre Journal. 48(1):59-78.

Federici, Eleanora (2011): The visibility of the woman translator. In: Eleanora Federici, ed. Translating Gender. New York: Peter Lang. 79-91.

Finney, Gail (1994): Ibsen and feminism. In: James McFarlane, ed. The Cambridge Companion to Ibsen. Cambridge: Cambridge University Press, 89-105.

Fischer-Lichte, Erika (2011): Global Ibsen: Performing Multiple Modernities. New York: Routledge.

FLOTOW, Luise von (1991): Feminist translation: contexts, practices and theories. TTR. 4(2):69-84.

Flotow, Luise von (1997): Translation and Gender: Translation in the Era of Feminism. Manchester: St. Jerome.

Flotow, Luise von (2005): Tracing the context of Translation: the importance of Gender. In: José Santaemilia, ed. Gender, Sex and Translation: The Manipulation of Identities. Manchester: St. Jerome, 39-52.

Flotow, Luise von (2011): Translating Women. Ottawa: University of Ottawa Press.

Flotow, Luise von and Farahzad, Farzaneh (2017): Introduction. In: Luise von Flotow and Farzaneh Farahzad, eds. Translating Women: Different Voices and New Horizons. New York: Routledge, xiii-xvi.

Godard, Barbara (1990): Theorizing Feminist Discourse/Translation. In: Susan BAssnetT and André Lefevere, eds. Translation, History and Culture. London: Pinter, 87-97.

Gregersen, Halfdan (1936): Ibsen and Spain. Cambridge: Harvard University Press.

Hermans, Theo (1985): The Manipulation of Literature: Studies in Literary Translation. London: Croom Helm.

Hermans, Theo (2009): Translation, ethics, politics. In: Jeremy Munday, ed. The Routledge Companion to Translation Strategies. New York: Routledge, 93-105

Holledge, Julia and Tompkins, Joanne (2000): Women's Intercultural Performance. New York: Routledge.

Holledge, Julie, Helland, Frode, Tompkins, Joanne, and Bollen, Jonathan (2016): A Global Doll's House. Ibsen and Distant Visions. New York: Palgrave Macmillan.

Langås, Unni (2005). What did Nora Do? Thinking Gender with A Doll's house. Ibsen Studies. 5(2):148-171.

Leonardi, Vanessa and Taronna, Annarita (2011): Translators vs. Translatresses' strategies: ethical and ideological challenges. MonTI. 3:377-402.

Lizárraga Vizcarra, Isabel and Aguilera Sastre, Juan (2010): De Madrid a Ginebra: el feminismo español y el VIII Congreso de la Alianza Internacional de la Mujer. Madrid: Icaria.

Martínez Sierra, Gregorio [María Lejárraga] (1917a): Conferencia. In: Henrik Ibsen. Casa de muñecas. (Translated by Gregorio Martínez Sierra [María Lejárraga]) Madrid: Renacimiento, 9-23.

Martínez Sierra, Gregorio [María LejÁRraga] (1917b): De feminismo. In: Gregorio Martínez Sierra [María Lejárraga]. Feminismo, feminidad, españolismo. Madrid: Renacimiento, $11-43$. 
Martínez Sierra, María [María Lejárraga] (1953/2000): Gregorio y yo: medio siglo de colaboración. Valencia: Pre-Textos.

Mezei, Kathy (1989): Traverse. Tessera. 6:9-10.

Mobarak, Armin (2013): La recepción del teatro extranjero en Madrid (1900-1936). Doctoral dissertation, unpublished. Madrid: Universidad Complutense de Madrid.

MoI, Toril (2006): Henrik Ibsen and the Birth of Modernism. Oxford: Oxford University Press.

MuÑIZ, Iris Fernández (2016a): Tracking sources in indirect translation archaeology - a case study on a 1917 Spanish translation of Et Dukkehjem (1879). In: Turo Rautaoja, Tamara Mikolič Južnič and Kaisa Koskinen, eds. New Horizons in Translation Research and Education 4. Joensu: University of Eastern Finland, 115-132.

MuÑIZ, Iris Fernández (2016b): La España Moderna y la recepción temprana de Ibsen en España: en busca de la identidad del desconocido primer traductor español. Cartas Hispánicas. 006:1-27.

MuÑIZ, Iris (2018): A Doll's House of their own: Gregorio and Maria Martinez Sierra's feminist rewritings of Ibsen in Silver Age Spain. Doctoral dissertation, unpublished. Oslo: University of Oslo.

Nelken, Margarita (1930/2011): Las escritoras españolas. Madrid: Editorial Horas y Horas.

Nieva de la Paz, Pilar (1993): Autoras dramáticas españolas entre 1918 y 1936. (Texto y representación). Madrid: Consejo Superior de Investigaciones Científicas.

Ozimek-Maier, Janis (1980): Ibsen and Spain: a re-examination. Doctoral dissertation, unpublished. Madison: University of Wisconsin-Madison.

O’Connor, Patricia (1987): Gregorio y María Martínez Sierra: Crónica de una colaboración. Madrid: La Avispa.

O'Connor, Patricia (1988): Dramaturgas españolas de hoy: una introducción. Madrid: Espiral.

Palacios, Manuela (2014): Translation in the femenine: Theory, commitment and (good) praxis. Women's Studies International Forum. 24:87-93.

Romero López, Dolores (2015): Mujeres traductoras en la Edad de Plata (1868-1939): identidad moderna y affidamento. Hermēneus. 17:179-207.

Romero López, Dolores (2016): Retratos de traductoras en la Edad de Plata. Madrid: Escolar y Mayo.

SÁNCHEZ, Lola (2014): Productive paradoxes of a feminist translator: Carmen de Burgos and her translation of Möebius' treatise, The Mental inferiority of women (Spain, 1904). Women's Studies International Forum. 42:68-76.

Santaemilia, José (2011): Feminists translating: On Women, Theory and Practice. In: Eleanora Federici, ed. Translating Gender. New York: Peter Lang, 55-78.

Showalter, Elaine (1985): Toward a Feminist Poetics. In: Elaine Showalter, ed. The New Feminist Criticism: Essays on Women, Literature, and Theory. New York: Pantheon, 125-143.

Siguán, Marisa (2003): Ibsen en España. In: Javier Huerta Calvo, ed. Historia del teatro español: Del siglo XVIII a la época actual. Vol. 2. Madrid: Gredos, 2155-2179.

Simon, Sherry (1996): Gender in Translation: Cultural Identities and the Politics of Transmission. New York: Routledge.

Simón Palmer, María del Carmen (2010): Carmen de Burgos, traductora. Arbor. 186:157-168.

SMIDT, Kristin (2000): Ibsen translated. Oslo: Solum.

Templeton, Joan (1989): The Doll House Backlash: Criticism, Feminism and Ibsen. PMLA. 104(1):28-40.

WallmaCh, Kim (2006): Feminist translation strategies? Different or derived. Journal of Literary Studies. 22:1-26. 